\title{
Otomasi Pemisah Kulit Ari Kacang Kedelai dan Penyaringan pada Pembuatan Susu Kedelai di Desa Kutagandok
}

\author{
Gina Aulia Sari, Naura Mutia Astari, Vita Evelina, Billy Nugraha, Husna Rozaqqiyah \\ Program Studi S-1 Teknik Industri, Universitas Singaperbangsa Karawang, Jl. HS Ronggowaluyo, \\ Puserjaya, Kecamatan Telukjambe Timur, Karawang, 41361 \\ E-mail: ginaauliasari87@gmail.com
}

\begin{abstract}
Abstrak - Stunting secara umum adalah kondisi gagal pertumbuhan terhadap anak-anak, akibat kekurangan gizi dalam waktu lama. Susu memiliki kandungan gizi yang baik dan diperlukan oleh tubuh untuk proses pertumbuhan. Di Indonesia, masih banyak balita dan anak-anak yang tidak mengonsumsi susu sehingga dapat menyebabkan stunting. Hal tersebut dipengaruhi oleh tingginya harga susu di pasaran. Untuk mengatasi permasalahan, susu kedelai dapat menjadi solusi, karena mengandung zat yang setara dengan susu sapi. Desa Kutagandok merupakan salah satu desa stunting yang berada di Kabupatan Karawang. Penanggulangan yang dilakukan desa untuk mengurangi angka stunting adalah dengan pemberian susu kedelai kepada balita dan anak-anak. Proses produksi susu kedelai dilakukan oleh masyarakat Desa Kutagandok. Masih terdapat beberapa kendala dalam produksi, yaitu terbatasnya sumber daya manusia (SDM) untuk proses pemisahan kacang kedelai dengan kulit ari. Dibutuhkan SDM yang lebih banyak untuk membuat waktu produksi menjadi lebih singkat. Selain itu, lamanya waktu penyaringan susu kedelai mengakibatkan mudah basi. Tujuan dari pengabdian ini adalah untuk membantu desa mengurangi angka stunting, dengan cara otomasi alat pengupas kacang kedelai kulit ari dan alat penyaring untuk memisahkan susu kedelai dengan ampasnya. Awalnya proses produksi susu kedelai digunakan dengan cara konvensional. Pengabdian ini menggunakan alat pengupas semi-konvensional. Dengan adanya alat penyaring yang baru waktu proses produksi lebih cepat dan kualitas menjadi lebih baik.
\end{abstract}

Kata Kunci — konvensional, otomasi, semi-konvesional, stunting, susu kedelai

\begin{abstract}
Stunting in general is a failure condition growth against children, caused by malnutrition in a long time. Milk has a good nutritional content and required by the body for the process of growth. In Indonesia, there are still many toddlers and children who do not consume milk that can cause stunting. It is influenced by the high milk prices in the market. To overcome the problem, soy milk can be a solution, because it contains a substance which is equivalent to cow's milk. The village Kutagandok is one of the villages stunting, which is located in Karawang District. Countermeasures carried out of the village to reduce stunting is the provision of soy milk to toddlers and kids. The process of the production of soy milk is made by the people of the village Kutagandok. But the thing is, there are still some obstacles in the production of, namely the limited human resources (HR) for the separation process soy beans with the skin's epidermis. So then it takes a HR more to make the production time to be shorter. In addition, the length of time filtering soy milk which resulted in easy casserole. The purpose of this service is to help the village of reducing stunting, by way of automation peeler soybeans from the epidermis and the filter tool to separate the soy milk with the dregs. Initially the process of the production of soy milk is used in a conventional manner. Furthermore, through this service uses the peeler semi-conventional. With the filter tool, then the time the production process is faster and quality is better.
\end{abstract}

Keywords — conventional, automation, semi-conventional, stunting, soy milk 


\section{PENDAHULUAN}

Salah satu cara untuk memenuhi kebutuhan asupan zat dalam tubuh manusia dengan mengonsumsi susu [1]. Susu memiliki kandungan gizi yang seimbang seperti protein, lemak, karbohidrat, vitamin, mineral dan air. Selain itu, susu mudah dicerna oleh sistem percernaan manusia. Susu didapatkan dengan cara pemerahan pada hewan yang menyusui. Di Indonesia, masih banyak balita dan anak-anak yang memiliki masalah mengenai gizi [2]. Permasalahan tersebut dikarenakan kurangnya asupan berbagai zat di dalam tubuh. Selain itu, tingginya harga susu juga berpengaruh. Salah satu cara untuk meningkatkan gizi adalah dengan mengonsumsi susu kedelai [3]. Selain memiliki harga yang terjangkau untuk masyarakat, susu kedelai dapat digunakan untuk mengganti peran susu sapi [4]. Hal ini dapat menjadi salah satu solusi bagi seseorang yang memiliki alergi terhadap susu sapi. Tentunya susu kedelai dapat menjadi solusi alternatif untuk memenuhi asupan gizi yang setara dengan susu sapi.

Susu kedelai memiliki berbagai macam diantaranya: cocok untuk dikonsumsi bagi penderita diabetes melitus dan laktose intolerant [5]. Susu kedelai memiliki gizi yang tinggi, karena mengandung protein $3,5 \mathrm{~g} / 100 \mathrm{~g}$ yang setara dengan susu sapi [1]. Selain itu, bagi yang sedang melakukan program diet mengonsumsi susu kedelai sangat baik [3]. Hal ini disebabkan dari kandungan lemak yang lebih rendah. Susu kedelai bermanfaat untuk pembentukan tulang dan gigi, karena mengandung fosfor dan kalsium [4]. Maka sangat baik jika dikonsumsi oleh anak-anak.

\section{ANALISIS SITUASI}

Desa Kutagandok berada di Kecamatan Kutawaluya Kabupaten Karawang dengan luas wilayah 5,62 $\mathrm{km}^{2}$. Desa Kutagandok merupakan masyarakat yang mayoritas pekerjaannya sebagai petani, peternak dan buruh. Secara kondisi perekonomian mayoritas menengah ke bawah. Desa Kutagandok merupakan salah satu produsen yang memproduksi susu kedelai. Susu yang diproduksi di desa ditujukan untuk balita dan anak-anak di wilayah mereka. Hal ini dikarenakan termasuk ke dalam deretan desa stunting. Stunting terjadi karena ketidakcukupan asupan energi, zat gizi makro dan zat gizi mikro dalam jangka waktu panjang [6]. Selain itu, stunting juga diakibatkan oleh infeksi yang terjadi secara berulang [5]. Melihat permasalahan tersebut, program ini berusaha untuk turut serta menurunkan angka stunting di Desa Kutagandok.

Setiap pembuatan susu kedelai membutuhkan waktu yang cukup lama [4]. Proses produksi susu kedelai dimulai dari perendaman susu kedelai selama 8 jam. Setelah itu, dilakukan pengupasan kacang kedelai yang masih terdapat kulit ari. Selanjutnya dilakukan penyaringan yang memisahkan antara susu dengan ampasnya secara manual tanpa alat [7]. Hasil produksi yang dihasilkan menjadi lebih sedikit. Adapun permasalahan yang dialami pada saat produksi susu kedelai, yaitu terbatasnya SDM. Agar waktu produksi menjadi lebih singkat dibutuhkan SDM lebih banyak [7, 8]. Selain itu, lamanya waktu penyaringan susu kedelai menjadi faktor untuk susu kedelai mudah basi [9]. Gambaran pembuatan susu kedelai secara manual pada Gambar 1. di bawah ini. Dilakukan proses pemisahan kulit ari kacang kedelai secara manual. Pada proses tersebut dibutuhkan waktu dan tenaga manusia yang cukup banyak.

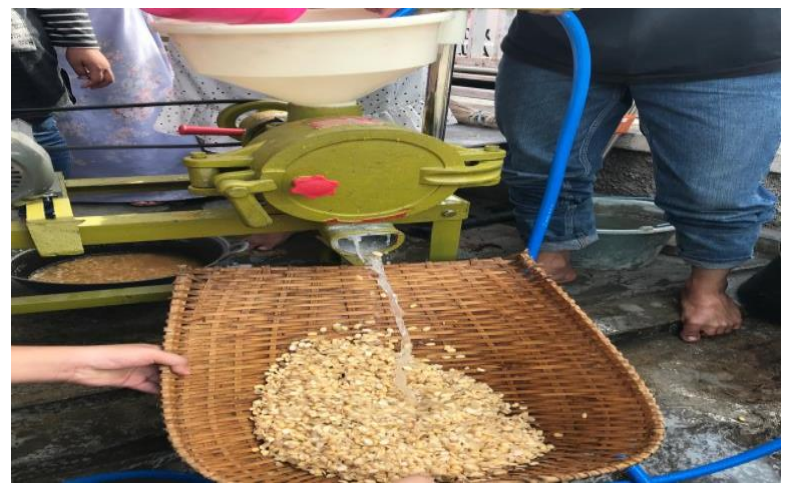

Gambar 1. Pemisahan Kacang Kedelai dengan Kulit Ari secara Manual

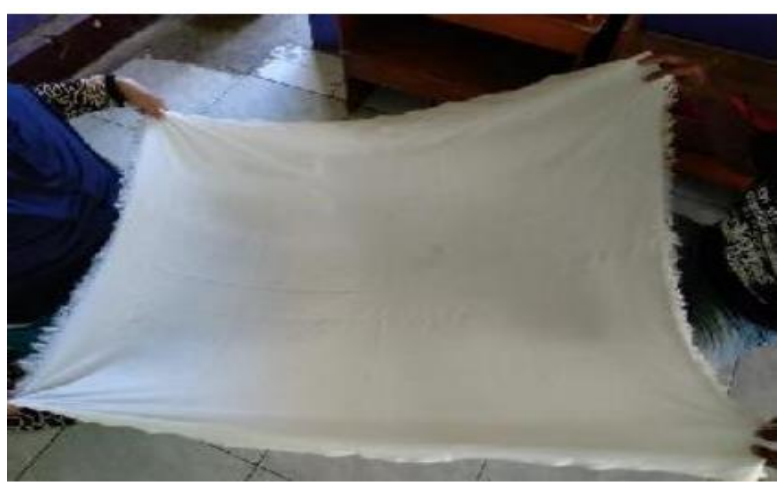

Gambar 2. Alat Penyaring Susu Kedelai Tradisional 
Alat penyaring susu kedelai tradisional, seperti pada Gambar 2. di atas. Alat yang digunakan berupa kain katun. Kekurangan dari penggunaan alat ini adalah susu kedela tidak tersaring dengan baik dan membutuhkan waktu yang cukup lama. Hasil output menjadi mudah basi dan pembuatan menjadi tidak higienis.

Pemberian susu kedelai pada anak-anak di desa merupakan salah satu cara untuk menurunkan angka stunting. Program ini bertujuan untuk ikut serta membantu menurunkan angka stunting pada Desa Kutagandok. Hal ini dengan cara memperbaiki sistem produksi pada pembuatan susu kedelai. Adapun solusi yang dapat diberikan berupa: otomasi alat pengupas kacang kedelai dengan kulit ari. Selain itu, alat penyaring susu kedelai untuk memisahkan antara susu kedelai dengan ampas. Awalnya proses produksi susu kedelai digunakan dengan cara konvensional. Selanjutnya melalui program ini menggunakan alat pengupas semi-konvesional. Pengabdian ini dilaksanakan berdasarkan penelitian sebelumnya mengenai kacang kedelai baik dalam segi pengetahuan dan pengolahan kacang kedelai.

\section{METODE PELAKSANAAN}

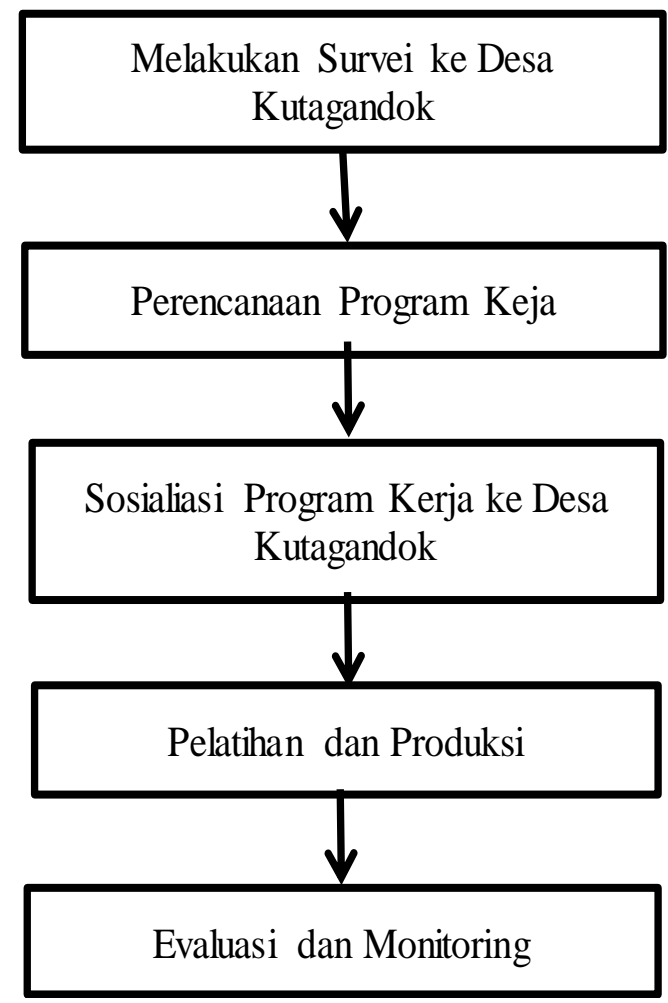

Gambar 3. Tahapan Kegiatan Program Pengabdian
Secara bertahap program pengabdian ini dilakukan seperti pada Gambar 3. di atas. Penjelasan dari tahapan program pengabdian yang dilakukan sebagai berikut:

1. Tim melakukan kunjungan ke Desa Kutagandok, Kecamatan Kutawaluya, Kabupaten Karawang secara langsung. Dengan tujuan untuk mengetahui permasalahan yang terjadi. Kunjungan ini merupakan langkah awal dalam pengabdian yang dilaksanakan pada Maret 2019. Selain itu, pada pengabdian ini berjumlah 11 orang.

2. Setelah mengetahui permasalahan yang dihadapi oleh desa. Maka tim melakukan perencanaan program kerja yang akan dilakukan di Desa Kutagandok.

3. Tim melakukan sosialisasi mengenai program kerja yang dibuat kepada Kepala Desa dan masyarakat Desa

4. Setelah memaparkan program kerja, Tim melakukan pelatihan kepada masyarakat secara langsung.

5. Monitoring dan evaluasi diadakan setiap satu bulan sekali guna mengetahui sejauh mana masyarakat sudah memahami hasil dari pelatihan produksi yang telah dilaksanakan.

\section{HASIL DAN PEMBAHASAN}

Langkah awal dari program ini adalah dengan mengunjungi desa. Kujungan pertama adalah menemui Kepala Desa Kutagandok. Berikut merupakan dokumentasi kunjungan pertama desa, seperti pada Gambar 4. di bawah ini.

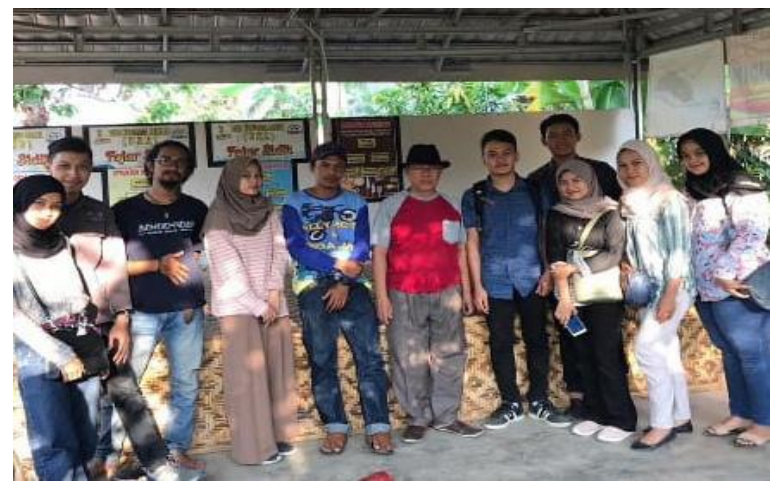

Gambar 4. Kunjungan Pertama ke Desa Kutagandok 
Hasil kunjungan pertama didapatkan bahwa Desa Kutagandok mengalami stunting. Kepala Desa Kutagandok memaparkan dengan pemberian susu kedelai kepada anak-anak bisa menurunkan angka stunting. Susu kedelai di Desa Kutagandok diproduksi oleh masyarakat di desa.

Selanjutnya tim melihat proses pembuatan susu kedelai secara langsung. Pembuatan susu kedelai di Desa Kutagandok dilakukan secara manual. Dari proses pembuatan susu kedelai masyarakat desa mengeluhkan proses pemisahan kulit ari kacang kedelai yang dilakukan secara satu persatu sehingga membutuhkan waktu yang lama dan terdapat kendala pada proses penyaringan susu kedelai yaitu apabila penyaringan susu kedelai tidak dilakukan dengan cara yang benar akan menyebabkan susu kedelai menjadi cepat basi. Setelah mengetahui permasalahan, maka tim melakukan penyusunan program pengabdian ini untuk mencari solusi terkait permasalahan tersebut. Tim memberikan usulan berupa mengotomasikan alat pengupas kulit ari dan alat penyaring susu kedelai. Dengan adanya alat penyaring susu kedelai, maka waktu proses produksi lebih cepat dan kualitas susu kedelai menjadi lebih baik. Hasil perancangan alat yang akan digunakan sebagai usulan pada Gambar 5.

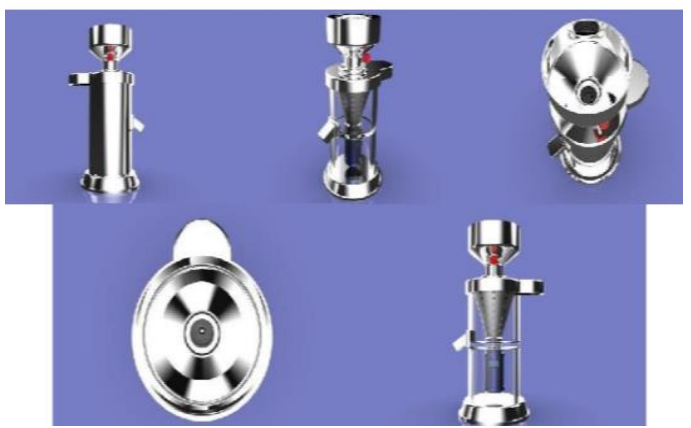

Gambar 5. Gambar Usulan Alat Penyaring Susu Kedelai

Langkah selanjutnya tim memaparkan hasil perancangan alat kepada Kepala Desa, termasuk masyarakat sekitar. Hasil perancangan alat yang akan digunakan oleh masyarakat. Keperluan proses produksi pada Gambar 6. Tim kemudian melaksanakan pelatihan terkait penggunaan hasil perancangan alat yang telah dibuat. Dengan tujuan agar masyarakat dapat dengan mudah menggunakannya.
Setelah selesai tahap pelatihan, maka tim melakukan evaluasi dan monitoring dalam satu bulan sekali. Tujuan dari evaluasi dan monitoring untuk mengetahui sejauh mana masyarakat memahami dan menggunakan alat yang telah dibuat. Hasil evaluasi dan montoring terdapat perubahan yang telah dirasakan oleh masyarakat. Hasil pernyataan tersebut didapat dari Tim melakukan diskusi, wawancara dan dokumentasi sebelum dan sesudah adanya program ini. Hasil yang signifikan terjadi pada proses pemisahan kulit ari dari kacang kedelai karena dilakukan secara satu persatu. dengan menggunakan alat pengupas ari akan mempercepat proses pemisahan karena hanya memerlukan waktu beberapa jam saja sesuai dengan kacang kedelai yang dipakai. Namun masih terdapat kendala pada saat menggunakan alat tersebut. Hal ini dikarenakan tegangan listrik yang kurang memadai. Setelah melakukan produksi pertama susu kedelai, tim memiliki beberapa perbaikan, yaitu kompoisi air dan kacang kedelai harus seimbang , apabila air yang ditambahkan itu kurang, maka alat penyaring susu kedelai menjadi tersumbat.

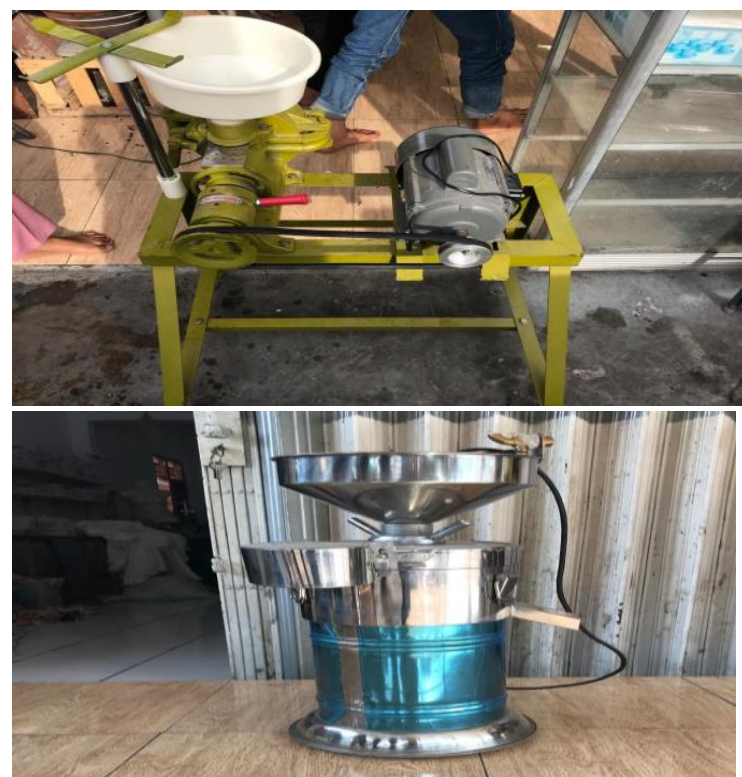

Gambar 6. Alat Pengupas Kulit Ari dan Penyaring Susu Kedelai 


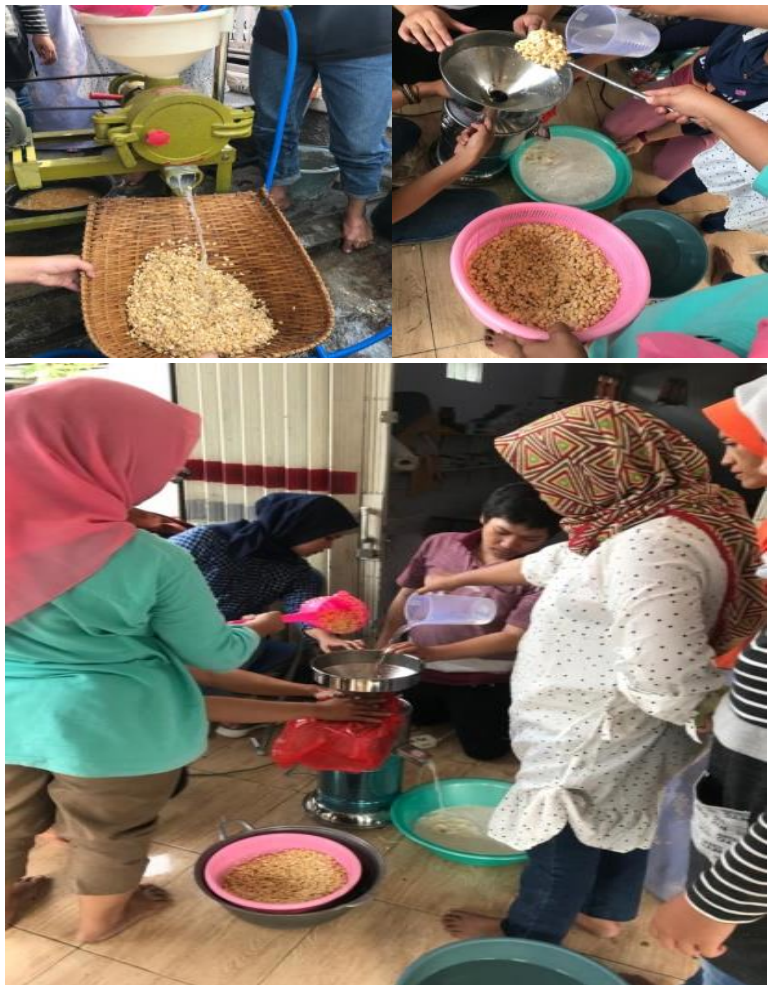

Gambar 7. Pelatihan Penggunaan Alat

\section{PENUTUP}

Kesimpulan dari berjalannya program ini, yaitu dengan menggunakan alat pengupas dan penyaring susu kedelai membuat waktu produksi susu kedelai menjadi lebih cepat dan menghasilkan susu kedelai yang lebih higienis dan lebih baik. Untuk itu diharapan permasalahan mengenai stunting pada anak-anak dapat berkurang jumlahnya.

Saran untuk program penelitian/pengabdian selanjutnya, yaitu pada perancangan alat kembali. Namun yang ditekankan pada penggunaan tegangan listrik. Hal ini dikarenakan alat tersebut membutuhkan energi listrik yang cukup banyak. Hasil ini tidak sejalan dengan kuantitas tegangan listrik di desa yang relatif kecil. Sehingga dari pengembangan selanjutnya dapat lebih optimal kembali.

\section{UCAPAN TERIMA KASIH}

Terimakasih disampaikan kepada Kementerian Riset dan Teknologi Republik Indonesia yang sudah memberikan dukungan pendanaan dalam program pengabdian di Desa Kutagandok, Kecamatan Kutawaluya, Kabupaten Karawang 2019. Universitas Singaperbangsa Karawang yang telah mendukung program pengabdian ini. Hasil program pengabdian ini dapat berjalan dengan baik.

\section{DAFTAR PUSTAKA}

[1] AAK, Kedelai, Yogyakarta: Kanisius, 1995.

[2] R. Endrasari and D. Nugrasari, "Pengaruh berbagai Cara Pengolahan Sari Kedelai terhadap Penerimaan Organoleptik," in Prosiding Seminar Nasional Optimalisasi Pekarangan, Semarang, 2012.

[3] Standar Nasional Indonesia (SNI), Susu Kedelai, Jakarta: Dewan Standarisasi Nasional, 1995.

[4] Muchtaridi, "Pembuatan Susu Kedelai," Fakultas Farmasi, Universitas Padjadjaran, Sukabumi, 2008.

[5] S. Yowono and T. Sutanso, Pengujian Fisik Pangan, Malang: Fakultas Teknologi Pertanian, Universitas Brawijaya, 1998.

[6] S. Sudarmadji, H. Bambang and Suhardi, Prosedur Analisa untuk Bahan Makanan dan Pertanian, Yogyakarta: Liberty, 1984.

[7] S. Wijatno, Pengantar Entrepreneurship, Jakarta: Grasindo, 2009.

[8] P. Kotler, Manajemen Pemasaran, Jakarta: PT. Prenhallindo, 2000.

[9] S. Widowati, "Teknologi Pengolahan Kedelai," in Kedelai: Teknik Produksi dan Pengembangan, Bogor, Balai Besar Penelitian dan Pengembangan Pascapanen Pertanian, 2007, pp. 491-521. 
